\title{
Some triterpenic compounds in extracts of Cecropia and Bauhinia species for different sampling years
}

\author{
Marcella Emilia Pietra Schmidt ${ }^{\mathrm{a}}$, Fernanda Brum Pires ${ }^{\mathrm{b}}$, Lucas Paines Bressan ${ }^{\mathrm{a}}$, \\ Fábio Vieira da Silva Jr. ${ }^{\mathrm{a}}$, Osmar Lameira ${ }^{\mathrm{c}}$, Marcelo Barcellos da Rosa ${ }^{\mathrm{a}, \mathrm{b}, *}$ \\ a Programa de Pós-graduação em Química, Universidade Federal de Santa Maria, Camobi, Santa Maria, RS, Brazil \\ b Programa de Pós-graduação em Ciências Farmacêuticas, Universidade Federal de Santa Maria, Camobi, Santa Maria, RS, Brazil \\ ${ }^{\mathrm{c}}$ Embrapa Amazônia Oriental, Belém, PA, Brazil
}

\section{A R T I C L E I N F O}

\section{Article history:}

Received 9 October 2017

Accepted 24 November 2017

Available online 12 December 2017

\section{Keywords:}

HPLC-UV

Validation

Triterpenes

White and pink pata-vaca

Red and white-embaúba

Amazonian medicinal plants

\begin{abstract}
A B S T R A C T
The aim of this paper is to provide an overview on the chemical composition of triterpenes in widespread used folk medicine species, through the development and validation of eleven compounds using HPLCUV detection. The compounds were separated using isocratic elution, on a reverse phase column (Kinetex $\mathrm{C} 18,250 \mathrm{~mm} \times 4.6 \mathrm{~mm}, 5 \mu \mathrm{m})$ with mobile phase consisted of acetonitrile:tetrahydrofuran $(90: 10, \mathrm{v} / \mathrm{v})$, flow-rate of $0.5 \mathrm{ml} / \mathrm{min}$ and detection in $210 \mathrm{~nm}$. Diverse validation parameters were successfully evaluated. The samples of Bauhinia variegata L., B. variegata var. candida Voigt, Fabaceae, Cecropia palmata Willd. and C. obtusa Trécul, Urticaceae, collected in 2012, 2013 and 2014 from Amazon were treated with two different solvents (ethyl acetate and chloroform) and analyzed by the proposed method. Stigmasterol, lupeol, $\beta$-sitosterol, $\beta$-amirin and $\alpha$-amirin were found in all the studied plants. Highlighting the presence of oleanolic acid, maslinic acid in C. obtusa and C. palmata extracts, erythrodiol only in C. palmata, stigmasteol in B. variegata and $\alpha$-amirin in B. variegata var. candida. Overall, ethyl acetate showed better performance as the extractor solvent than chloroform. Moreover, it could be used for the quality control of medicinal plants and to assess potential marker compounds.
\end{abstract}

(C) 2017 Sociedade Brasileira de Farmacognosia. Published by Elsevier Editora Ltda. This is an open access article under the CC BY-NC-ND license (http://creativecommons.org/licenses/by-nc-nd/4.0/).

\section{Introduction}

Triterpenes, presents in vegetable oils, cereals, fruits and bark of trees are widespread in the human diet (Rhourri-Frih et al., 2009; Saleem, 2009; Siddique and Saleem, 2011; Szakiel et al., 2012) and one of the largest classes of secondary metabolites, with more than 30,000 different triterpenes reported (Muffler et al., 2011; Thimmappa et al., 2014).

This large number of compounds is related to the versatility of their structure, consisted of acycles, bi-, tri-, tetra- and pentacycles (Dias et al., 2011; Muffler et al., 2011). Among those, pentacyclic triterpenes presented promising pharmacological properties (Szakiel et al., 2012; Ghosh and Sil, 2013; Shanmugam et al., 2013) such as, anti-inflammatory (Saleem et al., 2008; Martelanc et al., 2009), hepatoprotector (Kumari and Kakkar, 2012; Pollier and Goossens, 2012), anti-tumor (Saleem, 2009; Shanmugam et al., 2013), anti-viral (Sánchez-Ávila et al., 2009; Kong et al., 2013),

\footnotetext{
* Corresponding author.

E-mail: marcelo.b.rosa@ufsm.br (M.B. Rosa).
}

anti-HIV (Cheng et al., 2011; Wójciak-Kosior et al., 2013), antimicrobial (Pai et al., 2011), anti-fungal (Rocha et al., 2004), anti-diabetic (Manna et al., 2010), gastroprotective (Sánchez et al., 2006; Quílez et al., 2010), anti-hyperlipidemic (Claude et al., 2004), neuroprotector (Silva et al., 2011), antiarthritic (Siddique and Saleem, 2011), antioxidant (Allouche et al., 2010), cholesterol-reducing properties (Chauhan et al., 2013), cardioprotective (Somova et al., 2003) and trypanocidal activity (Ferreira et al., 2010).

Medicinal plants have been used for centuries in folk medicine associated with health promotion, prevention and cure of human diseases (Laszczyk, 2009; Romero et al., 2010). With more than 50,000 plant species, Brazil has the greatest levels of biodiversity in the planet (Giulietti et al., 2005) and Amazonia is a region with one of the richest flora in the world with a large potential discovery and research of new drugs (Giulietti et al., 2005; Coelho-Ferreira, 2009). Despite the diversity and the widespread use of phytotherapics in Brazil the scientific knowledge about this flora properties is limited (Figueredo et al., 2014).

Bauhinia variegata L., popular known in Brazil as "pata-de-vaca" or "unha-de-boi", member of the Fabaceae family, it has been 
used in popular medicine as a result of their hypoglycemic (Silva and Filho, 2002; Parekh et al., 2006; Murillo et al., 2007; Silva et al., 2007), anti-cholesterol, anti-elephantiasis (Silva et al., 2007), antibacterial (Silva and Filho, 2002; Parekh et al., 2006), anti-tumor (Rajkapoor et al., 2003), antifungal (Silva and Filho, 2002; Rajkapoor et al., 2003), diuretic, tonic, depurative activities (Pizzolatti et al., 2003), while also being useful against skin diseases and ulcers (Reddy et al., 2003) in bronchitis, leprosy (Rajkapoor et al., 2003), and in the management of inflammatory diseases (Silva and Filho, 2002; Rao et al., 2008).

Another medicinal plants included in this study is Cecropia palmata Willd. and C. obtusa Trécul, popularly known in Brazil as "embaúba-vermelha" and "embaúba-branca" from the Urticaceae family, traditional used as anti-rheumatic (Silva et al., 2007), antiinflammatory (Rocha et al., 2007; Costa et al., 2011; Nicasio-Torres et al., 2012; Pelaez et al., 2013), anti-oxidant activities (NicasioTorres et al., 2012), anti-tumor (Rocha et al., 2007), act in central nervous system, including anxiolytic and antidepressant-like activities (Silva et al., 2007; Costa et al., 2011), against asthma, high blood pressure (Costa et al., 2011), as well used in the treatment of type 2 diabetes (Rocha et al., 2007; Nicasio-Torres et al., 2012; Pelaez et al., 2013).

This wide diversity of pharmacological properties reported in Cecropia and Bauhinia is related to secondary metabolites, as flavonoids, phenolic acids, carotenoids, tocopherols, alkaloids, lignans, tannins, salicylates, glucosinolates and triterpenes (Szakiel et al., 2012).

Several papers described the detection and separation of triterpenes in medicinal plants. Some methods include preparative thin-layer chromatography (TLC) (Martelanc et al., 2007; Martelanc et al., 2009), gas chromatography (GC) with derivatization step (Zhang et al., 2012), capillary electrophoresis (CE) (Cheung and Zhang, 2008; Li et al., 2011), evaporative light-scattering detectors (Lesellier et al., 2012), high-performance liquid chromatography (HPLC) (Martelanc et al., 2009; Li et al., 2011; Lesellier et al., 2012; Zhang et al., 2012) with UV detector or mass spectrometric detectors using atmospheric pressure chemical ionization (APCI) atmospheric pressure photoionization (APPI) and electrospray ionization (ESI)(Sánchez-Ávila et al., 2009). The simultaneous determination of triterpenes render a difficult task considering, their similar structure, lack of chromophores, very low UV absorption and similar polarity. According to the literature, there is only one published report that separates more than six triterpenes in a single HPLC run (Bedner et al., 2008; Martelanc et al., 2009; Sánchez-Ávila et al., 2009; Li et al., 2011; Slavin and Yu, 2012; Li et al., 2013).

In this study the development of a method for simultaneous determination of eleven triterpenes with isocratic elution and UV detection was proposed. The developed method was applied to the analysis of four different medicinal plants from the Amazon region (Cecropia obtusa, C. palmata, B. variegata and B. variegata var. candida) HPLC with UV detection.

\section{Materials and methods}

\section{Chemicals}

All the chemical standards used, $\alpha$-amirin (98\%), $\beta$-amirin (98.5\%), $\beta$-sitosterol (85\%), stigmasterol (95\%), lupeol (90\%), uvaol (95\%), erythrodiol (97\%), oleanolic acid (97\%), betulinic acid (97\%), arjunic acid (88\%) and maslinic acid (95\%) used were of analytical grade from Sigma-Aldrich (St. Louis, MO, USA). The solvents acetonitrile $(\mathrm{ACN})$, methanol $(\mathrm{MeOH})$ and tetrahydrofuran (THF) were of HPLC grade from Tedia (Fairfield, OH, EUA). Chloroform $\left(\mathrm{CHCl}_{3}\right)$ and ethyl acetate (EtOAc) were of analytical grade from
Merck (Darmstadt, Germany). Stock solutions of $\alpha$-amirin, $\beta$ amirin, uvaol, erythrodiol, oleanolic acid, arjunic acid and maslinic acid $1000 \mathrm{mg} / \mathrm{l}$, stigmasterol $481 \mathrm{mg} / \mathrm{l}$, lupeol $365 \mathrm{mg} / \mathrm{l}$, betulinic acid $196 \mathrm{mg} / \mathrm{l}$ and $\beta$-sitosterol $873 \mathrm{mg} / \mathrm{l}$ were prepared in methanol. The working analytical solutions for analytical curve were obtained by diluting the analytical solutions in acetonitrile with the following concentrations $0.7,6.5,12.2,18.0,23.6,29.3$ and $35.0 \mathrm{mg} / \mathrm{l}$. All the solutions were stored at $-20^{\circ} \mathrm{C}$ until analysis.

\section{HPLC-UV analysis}

Chromatographic measurements were performed on a Dionex ${ }^{\circledR}$ model P680 (Sunnyvale, CA, USA) liquid chromatograph equipped with a UV-vis detector model UVD170U, Rheodyne ${ }^{\circledR}$ injection valve model 8125 (Cotati, CA, USA) with loop of $100 \mu$ l. The analyses were carried out with a Kinetex reversed-phase $C_{18}$ column ( $250 \mathrm{~mm} \times 4.6 \mathrm{~mm}, 5 \mu \mathrm{m}$ particle size; Phenomenex, Torrance, CA, USA) which was preceded by a Security Guard $C_{18}$.pre-column (Phenomenex, Torrance, CA, USA). The mobile phase consisted of acetonitrile:tetrahydrofuran $(90: 10, \mathrm{v} / \mathrm{v})$ and the flow-rate was set at $0.5 \mathrm{ml} / \mathrm{min}$. Spectrophotometry detection of analytes was performed at $210 \mathrm{~nm}$ wavelengths. Evaluation and quantification were made on a Chromeleon 6.7 Workstation. The same samples were previously studied also by performing an ultra-high-performance liquid chromatography - atmospheric pressure photoionization source mass spectrometry (UHPLC-APPI-MS/MS). Therefore, a comparison of the species detected using HPLC-UV was performed by UHPLC-APPI-MS/MS, described in details by Gobo et al. (2016).

\section{Plant material}

The medicinal plant species Bauhinia variegata $\mathrm{L}$. (deposit $\mathrm{n}^{\circ}$ IAN 185932), B. variegata var. candida Voigt (deposit $n^{\circ}$ IAN 185831), Cecropia obtusa Trécul (deposit n ${ }^{\circ}$ IAN 185555) and C. palmata Willd (deposit $n^{\circ}$ IAN 185556) were obtained from the herbal collection of the Brazilian Agricultural Research Corporation, Embrapa Amazônia Oriental, Belém, PA, Brazil. The geographical location of the collection site is $1^{\circ} 27^{\prime} 21^{\prime \prime}$ S latitude and $48^{\circ} 30^{\prime} 14^{\prime \prime} \mathrm{W}$ longitude.

The Amazon region has a hot and humid characteristic climate with small temperature gradients. There are two well establish seasons in that region, a dry-period (July-October) and rainy season (December-May); the months of June and November are considered transition periods (Ananias et al., 2010). According Gobbo-Neto and Lopes (2007) there is a positive influence of rainfall on the concentration of secondary metabolites (cyanogenic glycosides, glucosinolates, terpenes, anthocyanins and alkaloids) therefore, the samples studied were collected during the rainy season in three different years (2012, 2013 and 2014).

\section{Sample preparation and extraction procedure}

The fresh plant specimens were cleaned, dried at $40^{\circ} \mathrm{C}$ for $12 \mathrm{~h}$, ground into a fine powder in a laboratory mill and used as a dry powdered material. All plants were received as a fine powdered dried leaf material. Dried samples were stored in desiccators under vacuum at room temperature until sample treatment.

Ultrasound-assisted extraction was performed in a reactor thermostatic water bath (temperature accuracy of $\pm 1.0^{\circ} \mathrm{C}$ ). The experimental setup consists of an ultrasonic bath USC $1800 \mathrm{~A}$ (Unique Inc., Brazil, BR) equipped with a transducer with longitudinal vibrations. The ultrasonic unit has an operating frequency of $40 \mathrm{kHz}$ and a maximum-rated ultrasound power output of $132 \mathrm{~W}$. The ultrasonic transducer (surface area of $282.2 \mathrm{~cm}^{2}$ ) is fitted at the bottom of the bath horizontally along the length of the bath (Dal Prá et al., 2015). Samples were weighed $0.5 \mathrm{~g}$ and placed into a conical flask, into which $10 \mathrm{ml}$ of ethyl acetate or chloroform was added 
and sonicated for $30 \mathrm{~min}$ at $37^{\circ} \mathrm{C}$. Extraction was carried out three times with fresh portions of solvent in the above conditions (Pai et al., 2011; Wójciak-Kosior et al., 2013). The extract remained was dried with $\mathrm{N}_{2}$ and dissolved in $10 \mathrm{ml}$ of mobile phase. All the samples were diluted to a $2 \%(\mathrm{~m} / \mathrm{v})$ and filtered through Chromafil Xtra PEFT-20/25 filters from Macherey-Nagel (Düren, Germany) before injection. For construction of the calibration curves, seven different mixed solutions were injected in three replicates.

\section{Validation procedure}

The analytical method was validated for linearity, limit of detection (LOD), limit of quantification (LOQ), accuracy, precision and robustness following the RE $n^{\circ} 899 / 2003$ (Anvisa, 2003). The calibration curves were prepared using seven concentrations $(0.7$, $6.5,12.2,18.0,23.6,29.3$ and $35.0 \mathrm{mg} / \mathrm{l}$ ) of the 11 stock standard solutions in the range $0.21-40 \mathrm{mg} / \mathrm{l}$ which were injected in triplicate. The mean peak areas were taken for the construction the calibration curve. The data were analyzed by linear regression least square model. The LOD and LOQ under the presented chromatographic conditions were determined visually. The precision was determined by intra and inter-day variation and the recovery were evaluated by standard addition method, the variations were expressed by RSD \% as the following formula: RSD $(\%)=($ detected amount - original amount $) /$ amount spiked $\times 100$. All solutions were kept at $-20^{\circ} \mathrm{C}$ before analysis.

\section{Results and discussion}

\section{HPLC analysis}

Based in methods reported in the literature (Martelanc et al. 2007; Martelanc et al., 2009; Sánchez-Ávila et al., 2009; Yang et al., 2009; Li et al., 2013), chromatographic conditions were optimized in order to obtain the best separation of the analytes in the shortest time. The main variables evaluated in the chromatographic separation were ratio of the mobile phase, flow-rate of mobile phase, temperature of the operational room and detection wavelength. Table 1 shows these variables, the ranges studied and their optimum values as well as the solvents used in the optimization of the mobile phase composition.
Table 1

Optimization of the chromatographic conditions for separation of triterpenic compounds.

\begin{tabular}{lll}
\hline Variable & Tasted value & Optimum value \\
\hline $\begin{array}{l}\text { Flow rate }(\mathrm{ml} / \mathrm{min}) \\
\text { Room temperature }\left({ }^{\circ} \mathrm{C}\right)\end{array}$ & $0.5,0.8$ and 1.0 & 0.5 \\
Composition mobile phase & 21.0 and 23.0 & 21.0 \\
MeOH: $\mathrm{H}_{2} \mathrm{O}$ & $90: 10(\mathrm{pH} 3.0)$ & \\
& $80: 20(\mathrm{pH} 3.0)$ & \\
ACN: $\mathrm{H}_{2} \mathrm{O}$ & $90: 10(\mathrm{pH} 3.0)$ & ACN:THF $(90: 10)$ \\
THF: $\mathrm{ACN}: \mathrm{H}_{2} \mathrm{O}$ & $30: 60: 10$ & \\
ACN:THF & $90: 10$ & 210 \\
Wavelength $(\mathrm{nm})$ & $200,205,210,220$ & \\
& and 225 &
\end{tabular}

ACN, acetonitrile; $\mathrm{MeOH}$, methanol; THF, tetrahydrofuran; $\mathrm{H}_{2} \mathrm{O}$, water.

Table 2

Molar absorptivity coefficient $(\varepsilon)$ in $\mathrm{l} / \mathrm{mol} \mathrm{cm}$ of triterpenes in different wavelengths.

\begin{tabular}{llll}
\hline Compound & $\varepsilon_{200 \mathrm{~nm}}$ & $\varepsilon_{210 \mathrm{~nm}}$ & $\varepsilon_{220 \mathrm{~nm}}$ \\
\hline Arjunic acid & $2.4 \cdot 10^{4}$ & $1.6 \cdot 10^{4}$ & $6.4 \cdot 10^{3}$ \\
Betulinic acid & $5.0 \cdot 10^{3}$ & $5.7 \cdot 10^{3}$ & $2.2 \cdot 10^{3}$ \\
Erythrodiol & $7.1 \cdot 10^{4}$ & $2.8 \cdot 10^{4}$ & $1.2 \cdot 10^{4}$ \\
Lupeol & $1.2 \cdot 10^{5}$ & $6.1 \cdot 10^{4}$ & $3.1 \cdot 10^{4}$ \\
Maslinic acid & $2.2 \cdot 10^{5}$ & $1.5 \cdot 10^{5}$ & $7.1 \cdot 10^{4}$ \\
Oleanolic acid & $1.6 \cdot 10^{5}$ & $9.7 \cdot 10^{4}$ & $5.4 \cdot 10^{4}$ \\
Stigmasterol & $1.1 \cdot 10^{5}$ & $5.0 \cdot 10^{4}$ & $2.8 \cdot 10^{4}$ \\
Uvaol & $1.1 \cdot 10^{5}$ & $5.1 \cdot 10^{4}$ & $2.9 \cdot 10^{4}$ \\
$\alpha$-Amirin & $1.4 \cdot 10^{5}$ & $8.1 \cdot 10^{4}$ & $4.7 \cdot 10^{4}$ \\
$\beta$-Amirin & $1.3 \cdot 10^{5}$ & $4.6 \cdot 10^{4}$ & $2.4 \cdot 10^{4}$ \\
$\beta$-Sitosterol & $1.3 \cdot 10^{4}$ & $7.2 \cdot 10^{4}$ & $4.3 \cdot 10^{4}$
\end{tabular}

The best mobile phase was ACN/THF (90:10; v/v). The optimum flow rate and room temperature were $0.5 \mathrm{ml} / \mathrm{min}$ and $21^{\circ} \mathrm{C}$, respectively. The detection wavelength was chosen at $210 \mathrm{~nm}$ accordingly to experimental data (Table 2) and the literature (Holen, 1985; Schneider et al., 2009; Romero et al., 2010; Slavin and Yu, 2012; Xu et al., 2012; Zhang et al., 2012) due to better absorption at the selected wavelength. The representative chromatogram for standard solutions under the proposed conditions is shown in Fig. 1. It is noteworthy to mention that the complete separation of the eleven triterpenes could be achieved in $45 \mathrm{~min}$, compared to other separation methods, it can be said that the new methodology developed separates more compounds than the others reported

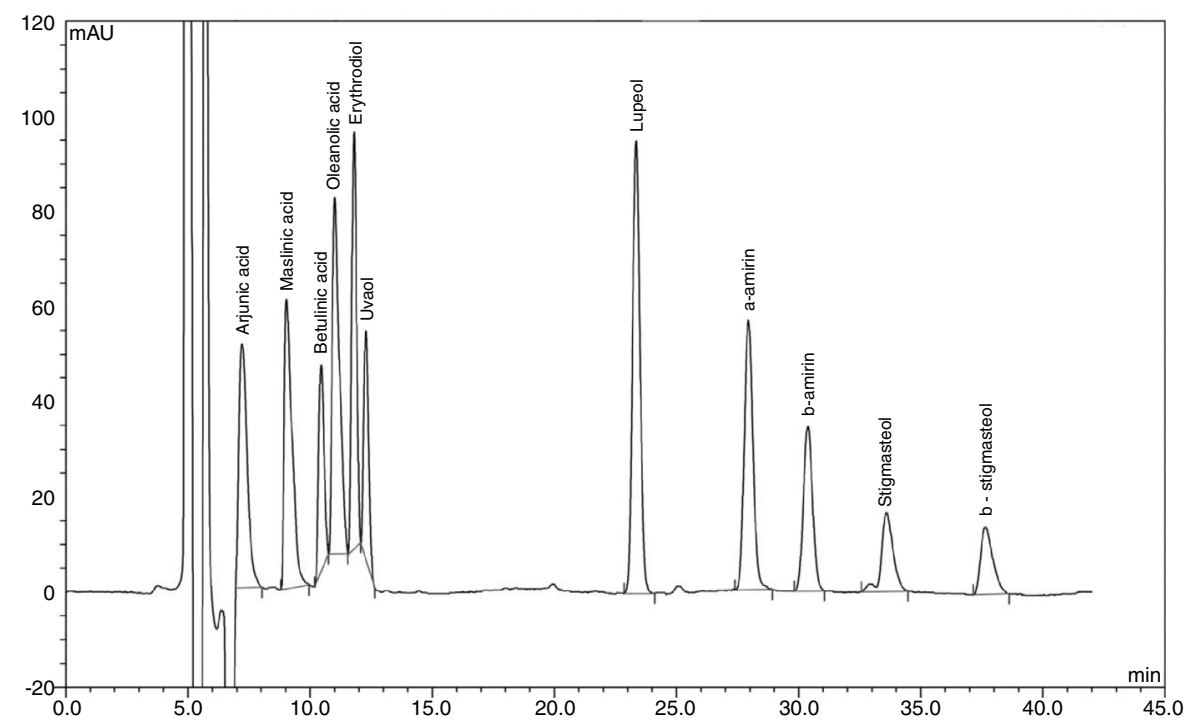

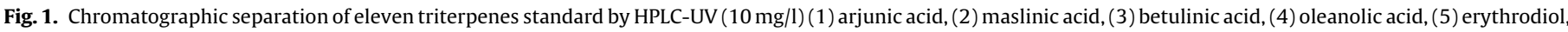

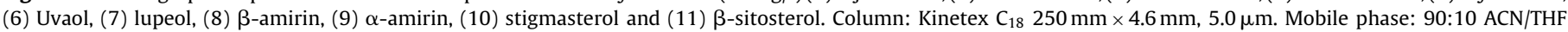
$0.5 \mathrm{ml} / \mathrm{min}$. 
Table 3

Analytical parameters for the validated method by HPLC-UV.

\begin{tabular}{|c|c|c|c|c|c|c|c|}
\hline Compound & $\mathrm{LOD}(\mathrm{mg} / \mathrm{kg})$ & $\mathrm{LOQ}(\mathrm{mg} / \mathrm{kg})$ & $\begin{array}{l}\text { Linear range } \\
(\mathrm{mg} / \mathrm{kg})\end{array}$ & $\begin{array}{l}\text { Correlation } \\
\text { coefficient }\left(r^{2}\right)\end{array}$ & $\begin{array}{l}\text { Intra-day precision } \\
\text { (RSD\%) }\end{array}$ & $\begin{array}{l}\text { Inter-day precision } \\
\text { (RSD\%) }\end{array}$ & Accuracy (\%) \\
\hline$\alpha$-Amirin & 0.37 & 0.75 & $0.74-40.0$ & 0.996 & 3.60 & 3.21 & $95-110$ \\
\hline$\beta$-Amirin & 1.04 & 2.12 & $0.74-40.0$ & 0.996 & 2.73 & 2.15 & $100-105$ \\
\hline Oleanolic acid & 0.22 & 0.43 & $0.74-35.0$ & 0.990 & 8.92 & 3.65 & $98-102$ \\
\hline Betulinic acid & 0.09 & 0.20 & $0.74-35.0$ & 0.996 & 9.38 & 3.40 & $93-97$ \\
\hline$\beta$-Sitosterol & 0.08 & 0.16 & $0.74-40.0$ & 0.992 & 3.95 & 3.19 & $97-110$ \\
\hline Stigmasterol & 0.06 & 0.13 & $0.74-40.0$ & 0.991 & 2.01 & 2.12 & $85-96$ \\
\hline Lupeol & 0.12 & 0.25 & $0.74-40.0$ & 0.996 & 2.43 & 2.54 & $92-102$ \\
\hline Uvaol & 0.12 & 0.24 & $0.74-35.0$ & 0.991 & 2.38 & 2.29 & $95-108$ \\
\hline Arjunic acid & 0.07 & 0.15 & $0.74-35.0$ & 0.990 & 4.01 & 3.75 & $97-103$ \\
\hline Maslinic acid & 0.13 & 0.27 & $0.74-40.0$ & 0.996 & 4.39 & 4.40 & $96-99$ \\
\hline Erythrodiol & 0.08 & 0.17 & $0.74-35.0$ & 0.994 & 2.16 & 1.85 & $90-96$ \\
\hline
\end{tabular}

LOD, limit of detection; LOQ limit of quantification; RSD, relative standard deviation.
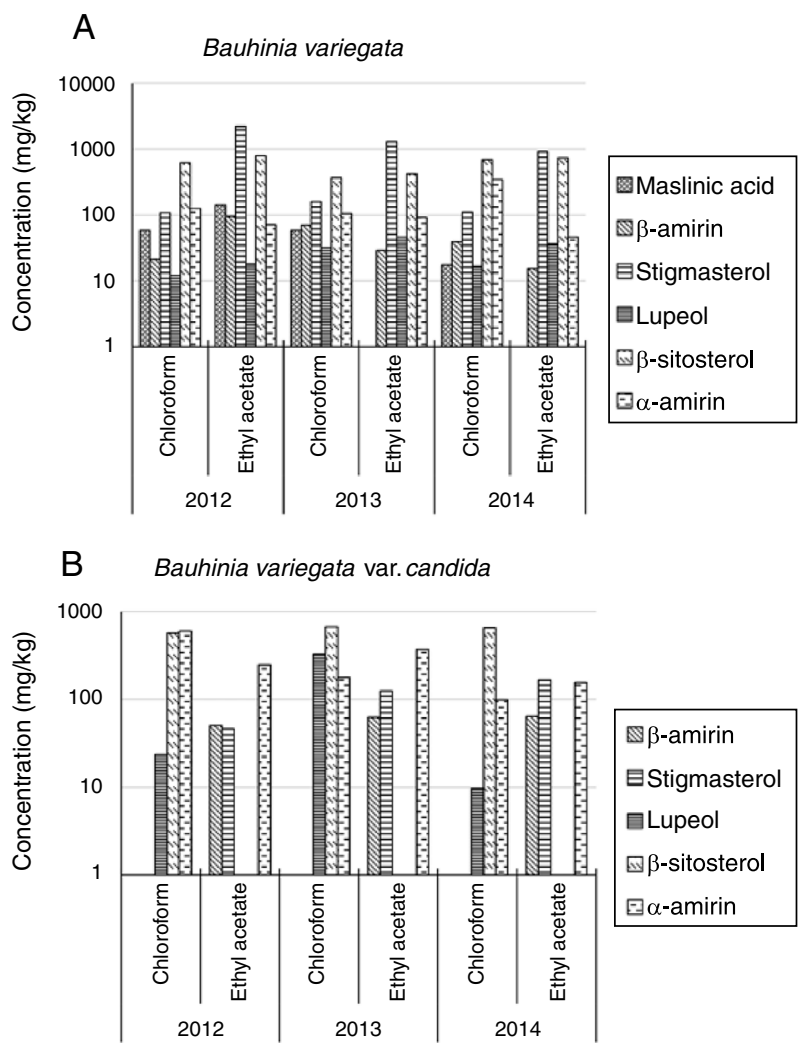

Fig. 2. Triterpenic compounds found in the Bauhinia species via HPLC-UV (A) Bauhinia variegata and (B) B. variegata var. candida.

in literature on isocratic mode (Liu et al., 2003; Ávila et al., 2007; Razboršek et al., 2007; Cheung and Zhang, 2008).

\section{Method validation}

The calibration curves showed good linearity and the correlation coefficients were found in the range of $0.990-0.996$ for all of the tested compounds. The recoveries of the eleven analytes were in the range of $85-110 \%$. The relative standard deviation (RSD) between sample measurements was used as precision, varying from 2.01 to $9.37 \%$ for intraday precision and from 1.84 to $4.04 \%$ to interday for precision. Robustness was tested in terms of flow difference $( \pm 0.1 \mathrm{ml} / \mathrm{min})$, \% mobile phase $( \pm 5 \% \mathrm{THF})$, and wavelength $( \pm 1 \mathrm{~nm})$. The variation does not exceed $20 \%$. Overall, these results demonstrate that the developed method has enough accuracy, precision, and sensitivity for the simultaneously quantitative analysis of the eleven compounds. The recovery results for evaluating the accuracy of the method were satisfactory according to the Anvisa (2003),

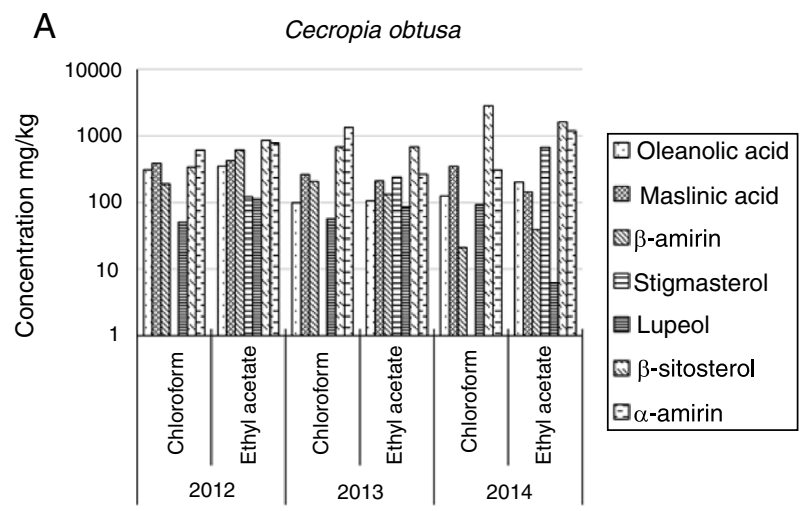

B

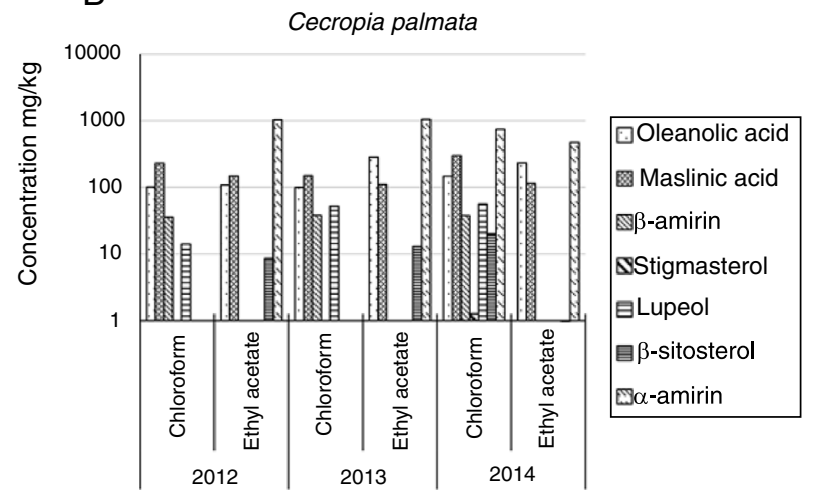

Fig. 3. Triterpenic compounds found in the Cecropia species via HPLC-UV (A) Cecropia obtusa and (B) Cecropia palmata.

which allows a range of $80-120 \%$ for amazon plants extracts. The obtained validation parameters such as correlation coefficient, linear range, recovery, LOD and LOQ are summarized in Table 3.

\section{Application to Bauhinia samples}

Previous studies in phytochemical analysis reported the presence of glycosides, triterpene, flavonoid, lactones, steroids, alkaloids, coumarins and saponins in Bauhinia species (Silva and Filho, 2002; Pizzolatti et al., 2003; Rajkapoor et al., 2003; Rao et al., 2008). Sample analysis (Fig. 2) indicated the presence of six (maslinic acid, stigmasterol, lupeol, $\beta$-sitosterol, $\beta$-amirin and $\alpha$ amirin) out of the eleven compounds in the Bauhinia species. The presence of the four compounds previously listed, using the same sample, was also confirmed previously by UHPLC-APPI-MS/MS analysis (Gobo et al., 2016).

Bauhinia variegata shows greater amounts of triterpenes in comparison with $B$. variegata var. candida. The use of ethyl acetate enabled to extract higher concentrations of stigmasterol $(+85 \%)$, 
lupeol $(+35 \%)$ and $\beta$-sitosterol $(+13 \%)$ in comparison with the chloroform.

\section{Application to Cecropia samples}

Regarding the studied compounds, C. obtusa (Fig. 3) exhibited a greater diversity when compared to the other species of the same genus analyzed $C$. palmata. Among the eleven triterpenes separated in this method oleanolic acid, maslinic acid, $\beta$-amirin, stigsmasterol, lupeol and $\beta$-sitosterol were found in these samples. $\beta$-amirin, lupeol and $\beta$-sitosterol were also identified by UHPLCAPPI-MS/MS analysis (Gobo et al., 2016).

Noteworthy is the presence of $\beta$-sitosterol $(+55 \%), \alpha$-amirin $(+60 \%), \beta$-amirin ( $+60 \%)$ and oleanolic acid $(+20 \%)$, increasing concentrations along the years, and the ethyl acetate was a better extract solvent than chloroform for these compounds. This observation can be a result of some environmental factors such as ultraviolet radiation, rainfall, temperature (Gobbo-Neto and Lopes, 2007).

\section{Conclusions}

A new analytical method has been developed for the simultaneous identification and quantification of triterpenes compounds using HPLC-UV and isocratic elution, to analyze these compounds in Cecropia and Bauhinia species. The HPLC-UV method is effective to separate and quantify the medicinal plants extracts with good validation parameters, such as linearity, LOD, LOQ, recovery, accuracy, precision, robustness and repeatability. Although triterpenoids contribute significantly to the bioactivity and pharmacology of Bauhinia and Cecropia, no study was reported so far for the quantitative determination of these compounds in these folk medicine plants. Triterpenes compounds such as maslinic acid, oleanolic acid, $\alpha$-amirin, $\beta$-amirin and $\beta$-sitosterol were found as major compounds in chloroform and ethyl acetate extracts. Furthermore, the presence of these triterpenic compounds in the extracts reinforces the pharmacological action, and the medical use of such plants in folk medicine. Based on the results, the species with the highest variety of compounds and concentration were $B$. variegata and C. obtusa. The present method developed can be used in research of chemical markers in medicinal plants as well as in the quality control of herbal medicines widely used in Brazil and in folk medicine. The identified compounds in Bauhinia (lupeol, $\beta$ sitosterol, $\beta$-amirin and $\alpha$-amirin), as well in Cecropia ( $\beta$-amirin, lupeol and $\beta$-sitosterol) extracts were also observed and using the same sample by HPLC-APCI-MS/MS analysis, therefore, ratifying the importance of this work.

\section{Authors' contributions}

MEPS, FBP and LPB developed and tested the proposed method. FVJr. gave a graphical and calculation support. OL collected the plants and performed the voucher. MBR was the advisor of MEPS, FBP, LPB and FVSJr. All the authors have read the final manuscript and approved its submission.

\section{Conflicts of interest}

The authors declare no conflicts of interest.

\section{Acknowledgements}

This work was supported by grants from the Brazilian Nacional Research Council CNPq, (processes 487028/2012-0 and
440132/2014-2). The authors also thank Embrapa Amazônia Oriental (Belém/PA) for supplying the medicinal plants studied.

\section{References}

Allouche, Y., Beltrán, G., Gaforio, J.J., Uceda, M., Mesa, M.D., 2010. Antioxidant and antiatherogenic activities of pentacyclic triterpenic diols and acids. Food Chem. Toxicol. 48, 2885-2890.

Ananias, D., Souza, E., Souza, P., Souza, A., Vitorino, M., Teixeira, G., Ferreira, D., 2010. Climatologia da estrutura vertical da atmosfera em novembro para Belém-PA. Rev. Bras. Meteorol. 25, 218-226.

Anvisa, 2003. Resolução - RE n ${ }^{\circ}$ 899, de 29 de Maio de 2003. Agência Nacional de Vigilância Sanitária, http://redsang.ial.sp.gov.br/site/docs_leis/vm/vm1.pdf (accessed 13.05.17)

Ávila, N.S., Capote, F.P., de Castro, M.L., 2007. Ultrasound-assisted extraction and silylation prior to gas chromatography-mass spectrometry for the characterization of the triterpenic fraction in olive leaves. J. Chromatogr. A 1165, 158-165.

Bedner, M., Schantz, M.M., Sander, L.C., Sharpless, K.E., 2008. Development of liquid chromatographic methods for the determination of phytosterols in standard reference materials containing saw palmetto. J. Chromatogr. A 1192, 74-80.

Chauhan, R., Ruby, K.M., Dwivedi, J., 2013. Secondary metabolites found in Bergenia species: a compendious review. Int. J. Pharm. Pharm. Sci. 5, 9-16.

Cheng, X.R., Jin, H.Z., Qin, J.J., Fu, J.J., Zhang, W.D., 2011. Chemical constituents of plants from the genus Geum. Chem. Biodivers. 8, 203-222.

Cheung, H.Y., Zhang, Q.F., 2008. Enhanced analysis of triterpenes, flavonoids and phenolic compounds in Prunella vulgaris L. by capillary zone electrophoresis with the addition of running buffer modifiers. J. Chromatogr. A 1213, 231-238.

Claude, B., Morin, P., Lafosse, M., Andre, P., 2004. Evaluation of apparent formation constants of pentacyclic triterpene acids complexes with derivatized $\beta$ - and $\gamma$ cyclodextrins by reversed phase liquid chromatography. J. Chromatogr. A 1049, 37-42.

Coelho-Ferreira, M., 2009. Medicinal knowledge and plant utilization in an Amazonian coastal community of Marudá Pará State (Brazil). J. Ethnopharmacol. 126, 159-175.

Costa, G.M., Ortmann, C.F., Schenkel, E.P., Reginatto, F.H., 2011. An HPLC-DAD method to quantification of main phenolic compounds from leaves of Cecropia species. J. Braz. Chem. Soc. 22, 1096-1102.

Dal Prá, V., Dolwitsch, C.B., Lima, F.O., de Carvalho, C.A., Viana, C., do Nascimento, P.C., da Rosa, M.B., 2015. Ultrasound-assisted extraction and biological activities of extracts of Brassica oleracea var. capitata. Food Technol. Biotechnol. 53, 102-109.

Dias, M.O., Hamerski, L., Pinto, A.C., 2011. Semi-preparative separation of $\alpha$ and $\beta$ amyrin by high performance liquid chromatographic. Quim. Nova 34, 704-706.

Ferreira da, D.S., Esperandim, V.R., Toldo, M.P.A., Saraiva, J., Cunha, W.R., Albuquerque de, S., 2010. Trypanocidal activity and acute toxicity assessment of triterpene acids. Parasitol. Res. 106, 985-989.

Figueredo de, C.A., Gurgel, I.G.D., Gurgel Junior, G.D., 2014. A Política Nacional de Plantas Medicinais e Fitoterápicos: construção, perspectivas e desafios. Physis 24, 381-400.

Ghosh, J., Sil, P.C., 2013. Arjunolic acid: a new multifunctional therapeutic promise of alternative medicine. Biochimie 95, 1098-1109.

Giulietti, A.M., Queiroz de, L.P., Wanderley, M.D.G.L., Van Den Berg, C., 2005. Biodiversidade e conservação das plantas no Brasil. Megadiversidade 1, 52-61.

Gobbo-Neto, L., Lopes, N.P., 2007. Plantas medicinais: fatores de influência no conteúdo de metabólitos secundários. Quim. Nova 30, 374-381.

Gobo, L.A., Viana, C., Lameira, O.A., de Carvalho, L.M., 2016. A liquid chromatographyatmospheric pressure photoionization tandem mass spectrometric (LC-APPIMS/MS) method for the determination of triterpenoids in medicinal plant extracts. J. Mass Spectrom. 51, 558-565.

Holen, B., 1985. Rapid separation of free sterols by reversed-phase high performance liquid chromatography. J. Am. Oil Chem. Soc. 62, 1344-1346.

Kong, L., Li, S., Liao, Q., Zhang, Y., Sun, R., Zhu, X., Zhang, Q., Wang, J., Wu, X., Fang, $\mathrm{X} ., 2013$. Oleanolic acid and ursolic acid: novel hepatitis $C$ virus antivirals that inhibit NS5B activity. Antiviral Res. 98, 44-53.

Kumari, A., Kakkar, P., 2012. Lupeol protects against acetaminophen-induced oxidative stress and cell death in rat primary hepatocytes. Food Chem. Toxicol. 50, 1781-1789.

Laszczyk, M.N., 2009. Pentacyclic triterpenes of the lupane, oleanane and ursane group as tools in cancer therapy. Planta Med. 75, 1549-1560.

Lesellier, E., Destandau, E., Grigoras, C., Fougère, L., Elfakir, C., 2012. Fast separation of triterpenoids by supercritical fluid chromatography/evaporative light scattering detector. J. Chromatogr. A 1268, 157-165.

Li, G.L., You, J.M., Song, C.H., Xia, L., Zheng, J., Suo, Y.R., 2011. Development of a new HPLC method with precolumn fluorescent derivatization for rapid, selective and sensitive detection of triterpenic acids in fruits. J. Agric. Food Chem. 59, 2972-2979.

Li, J.R., Li, M., Xia, B., Ding, L.S., Xu, H.X., Zhou, Y., 2013. Efficient optimization of ultra-high-performance supercritical fluid chromatographic separation of Rosa sericea by response surface methodology. J. Sep. Sci. 36, 2114-2120.

Liu, H., Shi, Y., Wang, D., Yang, G., Yu, A., Zhang, H., 2003. Determination of oleanolic acid and ursolic acid isomers in Ligustrum lucidum Ait. J. Pharm. Biomed. Anal. 32, 479-485.

Manna, P., Das, J., Ghosh, J., Sil, P.C., 2010. Contribution of type 1 diabetes to rat liver dysfunction and cellular damage via activation of NOS, PARP, IкB $\alpha / \mathrm{NF}-\kappa \mathrm{B}$ MAPKs, and mitochondria-dependent pathways: prophylactic role of arjunolic acid. Free Radic. Biol. Med. 48, 1465-1484. 
Martelanc, M., Vovk, I., Simonovska, B., 2007. Determination of three major triterpenoids in epicuticular wax of cabbage (Brassica oleracea L.) by highperformance liquid chromatography with UV and mass spectrometric detection. J. Chromatogr. A 1164, 145-152.

Martelanc, M., Vovk, I., Simonovska, B., 2009. Separation and identification of some common isomeric plant triterpenoids by thin-layer chromatography and highperformance liquid chromatography. J. Chromatogr. A 1216, 6662-6670.

Muffler, K., Leipold, D., Scheller, M.C., Haas, C., Steingroewer, J., Bley, T., Neuhaus, H.E., Mirata, M.A., Schrader, J., Ulber, R., 2011. Biotransformation of triterpenes. Process Biochem. 46, 1-15.

Murillo, E., Lombo, O., Tique, M., Méndez, J.J., 2007. Potencial antioxidante de Bauhinia kalbreyeri Harms (Fabaceae). Inf. Tecnol. 18, 65-74.

Nicasio-Torres, M. del P., Meckes-Fischer, M., Aguilar-Santamaría, L., GarduñoRamírez, M.L., Chávez-Ávila, V.M., Cruz-Sosa, F., 2012. Production of chlorogenic acid and isoorientin hypoglycemic compounds in Cecropia obtusifolia calli and in cell suspension cultures with nitrate deficiency. Acta Physiol. Plant. 34, 307-316.

Pai, S.R., Nimbalkar, M.S., Pawar, N.V., Dixit, G.B., 2011. Optimization of extraction techniques and quantification of betulinic acid (BA) by RP-HPLC method from Ancistrocladus heyneanus Wall. Ex Grah. Ind. Crops Prod. 34, 1458-1464.

Parekh, J., Karathia, N., Chanda, S., 2006. Evaluation of antibacterial activity and phytochemical analysis of Bauhinia variegata L. bark. Afr. J. Biomed. Res., http://dx.doi.org/10.4314/ajbr.v9i1.48773.

Pelaez, G.L.M., Sierra, J.A., Alzate, F., Holzgrabe, U., Ramirez-Pineda, J.R., 2013. Pentacyclic triterpenes from Cecropia telenitida with immunomodulatory activity on dendritic cells. Rev. Bras. Farmacogn. 23, 754-761.

Pizzolatti, M.G., Cunha Jr., A., Szpoganicz, B., Sousa, E.d., Braz-Filho, R., Schripsema, J., 2003. Flavonoids glycosides from leaves and flowers of Bauhinia forficata (Leguminosae). Quim. Nova 26, 466-469.

Pollier, J., Goossens, A., 2012. Oleanolic acid. Phytochemistry 77, 10-15.

Quílez, A., Berenguer, B., Gilardoni, G., Souccar, C., Mendonça, S., Oliveira de, L., Martín-Calero, M., Vidari, G., 2010. Anti-secretory, anti-inflammatory and antiHelicobacter pylori activities of several fractions isolated from Piper carpunya Ruiz \& Pav. J. Ethnopharmacol. 128, 583-589.

Rajkapoor, B., Jayakar, B., Murugesh, N., 2003. Antitumour activity of Bauhinia variegata on Dalton's ascitic lymphoma. J. Ethnopharmacol. 89, 107-109.

Rao, Y.K., Fang, S.H., Tzeng, Y.M., 2008. Antiinflammatory activities of flavonoids and a triterpene caffeate isolated from Bauhinia variegata. Phytother. Res. 22, 957-962.

Razboršek, M.I., Vončina, D.B., Doleček, V., Vončina, E., 2007. Determination of major phenolic acids, phenolic diterpenes and triterpenes in Rosemary (Rosmarinus officinalis L.) by gas chromatography and mass spectrometry. Acta Chim. Slov. 54, 60-67.

Reddy, M.V., Reddy, M.K., Gunasekar, D., Caux, C., Bodo, B., 2003. A flavanone and a dihydrodibenzoxepin from Bauhinia variegata. Phytochemistry 64, 879-882.

Rhourri-Frih, B., Chaimbault, P., Claude, B., Lamy, C., André, P., Lafosse, M., 2009. Analysis of pentacyclic triterpenes by LC-MS. A comparative study between APCI and APPI. J. Mass Spectrom. 44, 71-80

Rocha, A.D., Oliveira de, A.B., Souza Filho da, J.D., Lombardi, J.A., Braga, F.C., 2004. Antifungal constituents of Clytostoma ramentaceum and Mansoa hirsuta. Phytother. Res. 18, 463-467.

Rocha, G. da G., Simoes, M., Lúcio, K.A., Oliveira, R.R., Kaplan, M.A.C., Gattass, C.R., 2007. Natural triterpenoids from Cecropia lyratiloba are cytotoxic to both sensitive and multidrug resistant leukemia cell lines. Bioorg. Med. Chem. 15, 7355-7360.
Romero, C., García, A., Medina, E., Ruíz-Méndez, M.V., Castro de, A., Brenes, M., 2010 Triterpenic acids in table olives. Food Chem. 118, 670-674.

Saleem, M., 2009. Lupeol, a novel anti-inflammatory and anti-cancer dietary triterpene. Cancer Lett. 285, 109-115.

Saleem, M., Maddodi, N., Zaid, M.A., Khan, N., bin Hafeez, B., Asim, M., Suh, Y., Yun, J.-M., Setaluri, V., Mukhtar, H., 2008. Lupeol inhibits growth of highly aggressive human metastatic melanoma cells in vitro and in vivo by inducing apoptosis. Clin. Cancer Res. 14, 2119-2127.

Sánchez, M., Theoduloz, C., Schmeda-Hirschmann, G., Razmilic, I., Yáñez, T. Rodríguez, J.A., 2006. Gastroprotective and ulcer-healing activity of oleanolic acid derivatives: in vitro-in vivo relationships. Life Sci. 79, 1349-1356.

Sánchez-Ávila, N., Priego-Capote, F., Ruiz-Jiménez, J., de Castro, M.L., 2009. Fast and selective determination of triterpenic compounds in olive leaves by liquid chromatography-tandem mass spectrometry with multiple reaction monitoring after microwave-assisted extraction. Talanta 78, 40-48.

Schneider, P., Hosseiny, S., Szczotka, M., Jordan, V., Schlitter, K., 2009. Rapid solubility determination of the triterpenes oleanolic acid and ursolic acid by UV-spectroscopy in different solvents. Phytochem. Lett. 2, 85-87.

Shanmugam, M.K., Dai, X., Kumar, A.P., Tan, B.K., Sethi, G., Bishayee, A., 2013. Ursolic acid in cancer prevention and treatment: molecular targets, pharmacokinetics and clinical studies. Biochem. Pharmacol. 85, 1579-1587.

Siddique, H.R., Saleem, M., 2011. Beneficial health effects of lupeol triterpene: a review of preclinical studies. Life Sci. 88, 285-293.

Silva, E., Souza, J., Rogez, H., Rees, J.F., Larondelle, Y., 2007. Antioxidant activities and polyphenolic contents of fifteen selected plant species from the Amazonian region. Food Chem. 101, 1012-1018.

Silva da, K.A.S., Paszcuk, A.F., Passos, G.F., Silva, E.S., Bento, A.F., Meotti, F.C., Calixto J.B., 2011. Activation of cannabinoid receptors by the pentacyclic triterpene $\alpha \beta-$ amyrin inhibits inflammatory and neuropathic persistent pain in mice. Pain 152 1872-1887

Silva da, K.L., Filho, V., 2002. Plantas do gênero Bauhinia: composição química e potencial farmacológico. Quim. Nova 25, 449-454.

Slavin, M., Yu, L.L., 2012. A single extraction and HPLC procedure for simultaneous analysis of phytosterols, tocopherols and lutein in soybeans. Food Chem. 135, 2789-2795.

Somova, L., Nadar, A., Rammanan, P., Shode, F., 2003. Cardiovascular, antihyperlipidemic and antioxidant effects of oleanolic and ursolic acids in experimental hypertension. Phytomedicine 10, 115-121.

Szakiel, A., Paczkowski, C., Pensec, F., Bertsch, C., 2012. Fruit cuticular waxes as a source of biologically active triterpenoids. Phytochem. Rev. 11, 263-284.

Thimmappa, R., Geisler, K., Louveau, T., O’Maille, P., Osbourn, A., 2014. Triterpene biosynthesis in plants. Annu. Rev. Plant Biol. 65, 225-257.

Wójciak-Kosior, M., Sowa, I., Kocjan, R., Nowak, R., 2013. Effect of different extraction techniques on quantification of oleanolic and ursolic acid in Lamii albi flos. Ind. Crops Prod. 44, 373-377.

Xu, X.H., Su, Q., Zang, Z.H., 2012. Simultaneous determination of oleanolic acid and ursolic acid by RP-HPLC in the leaves of Eriobotrya japonica Lindl. J. Pharm. Anal. 2, 238-240.

Yang, G., Fen, W., Xiao, W., Sun, H., 2009. Study on determination of pentacyclic triterpenoids in Chaenomel by HPLC-ELSD. J. Chromatogr. Sci. 47, 718-722.

Zhang, Y.Y., Zhang, C., Ren, R., Liu, R., 2012. Simultaneous determination of seven major triterpenoids in Pyrola decorata $\mathrm{H}$. Andres by LC-MS method. Pharmazie $67,822-826$ 